\title{
TEMPERATURE MONITORING IN ŠKOCJANSKE JAME CAVES
}

\section{OPAZOVANJE TEMPERATURE V ŠKOCJANSKIH JAMAH}

ANDREJ KRANJC ${ }^{1} \&$ BOGDAN OPARA $^{2}$

${ }^{1}$ Karst Research Institute ZRS SAZU, Titov trg 2, SI-6230 POSTOJNA, SLOVENIA

${ }^{2}$ Brilejeva 3, SI-1000 LJUBLJANA, SLOVENIA 


\section{Andrej Kranjc \& Bogdan Opara: Opazovanje temperature v Škocjanskih jamah}

1884 je pričel J. Marinitsch meriti in zapisovati temperature v Škocjanskih jamah in njihovi okolici. Meritve za čas 1886-1914 so bile zabeležene v "Höhlenbuch". Leta 1928 so potekale podrobne mikroklimatske meritve sočasno v podzemlju in na površju. V letih 1960-1962 so člani ljubljanske univerze opravljali meteorološka opazovanja v jami in v udornici Velika dolina. 1992 so v okviru Inštituta pričeli z rednimi beleženji temperatur. Kasneje so v različne dele postavili 5 avtomatskih termometrov. Analizirani so rezultati dvoletnih opazovanj (maj 1997 - maj 1999) ter predstavljeni v tem prispevku. Čeprav so si letni povprečki precej podobni $\left(10,6^{\circ}\right.$ in $10,1^{\circ} \mathrm{C}$ ), kažejo mesečni povprečki velika nihanja (od $1,6^{\circ}$ do $17,3^{\circ} \mathrm{C}$ ), medtem ko so bile absolutne temperature $\mathrm{v}$ razponu od $-1,5^{\circ}$ do $21,9^{\circ} \mathrm{C}$. Najpomembnejša dejavnika za razporeditev temperature sta razdalja od vhoda in vertikalna lega. Primerjava temperature vode Reke in temperature zraka pri Mačji brvi kaže visoko stopnjo korelacije $\left(\mathrm{R}^{2}=0,8994\right)$. Predhodna opazovanja v tem kratkem času kažejo, da je del Škocjanskih jam, kjer teče Reka, izrazito dinamična jama in da obiskovalci ne morejo preveč vplivati na tamkajšnja meteorološka dogajanja.

Ključne besede: speleologija, varstvo jam, monitoring, temperatura, Škocjanske jame, Slovenija.

\section{Abstract}

UDK: 551.44.001.5(497.4 Škocjan)

\section{Andrej Kranjc \& Bogdan Opara: Temperature Monitoring in Škocjanske jame caves}

In 1884 J. Marinitsch started to measure and note down the data of temperature in the Škocjanske jame caves and nearby. The results for the period 1886-1914 are recorded in the "Höhlenbuch". During the year 1928 detailed microclimatic measurements are performed simultaneously on the surface and underground. In the years 1960-1962 the members of the Ljubljana University have carried on the meteorological observations in the cave and specially in the collapse doline Velika dolina. In 1992 Karst Research Institute started to monitor the temperatures. Later on 5 temperature recorders were placed into different parts of the cave. The results of the two years (May 1997 - May 1999) were analysed and are presented in this paper. Although the annual mean values are rather similar $\left(10.6^{\circ}\right.$ and $\left.10.1^{\circ} \mathrm{C}\right)$, there is a great amplitude between the monthly mean values $\left(1.6^{\circ}\right.$ to $\left.17.3^{\circ}\right)$. The absolute temperatures range between $-1.5^{\circ}$ and $21.9^{\circ} \mathrm{C}$. The most important factors are distance from the entrance, and the vertical position. The comparison between temperatures of the Reka river and the air temperatures bears an important correlation. Previous results of this short period already show that the part of Škocjanske jame, where the Reka river is flowing, is an extremely dynamic cave and the visitors cannot have much impact on it's meteorology.

Key words: speleology, cave protection, monitoring, temperature, Škocjanske jame, Slovenia. 


\section{INTRODUCTION}

In 1884 when Cave department of Littoral Section of DÖAV started to explore and to develop Škocjanske jame (caves) for tourism, one of the leaders, J. Marinitsch started to measure and note down the data of temperature in the caves and nearby. The data included free air temperatures at Divača and Motovun, air temperatures from different parts of the cave, the water temperature of the Reka river and the water level of the Reka. Often he had marked the weather too, and always the time when he was reading the data (Fig. 1). The results for the period 1886-1914 have been recorded in the so-called "Höhlenbuch" (Kranjc 1996) which was used to be kept in the museum "Haus der Natur" in Salzburg.

Between the $1^{\text {st }}$ and $2^{\text {nd }}$ World War the country Kras has been the Italian territory and Škocjanske jame were managed by "Sezione di Trieste del Club Alpino Italiano, Società Alpina delle Giulie (Iviani 1934). In 1928 they undertook speleoclimatic observations too. During the whole year the detailed microclimatic measurements (5 thermographs and 5 mini-maxi thermometres) are performed simultaneously on the surface and underground. Relatively full and detailed results have been published in an Italian journal (Fig. 2) (Vercelli 1931).

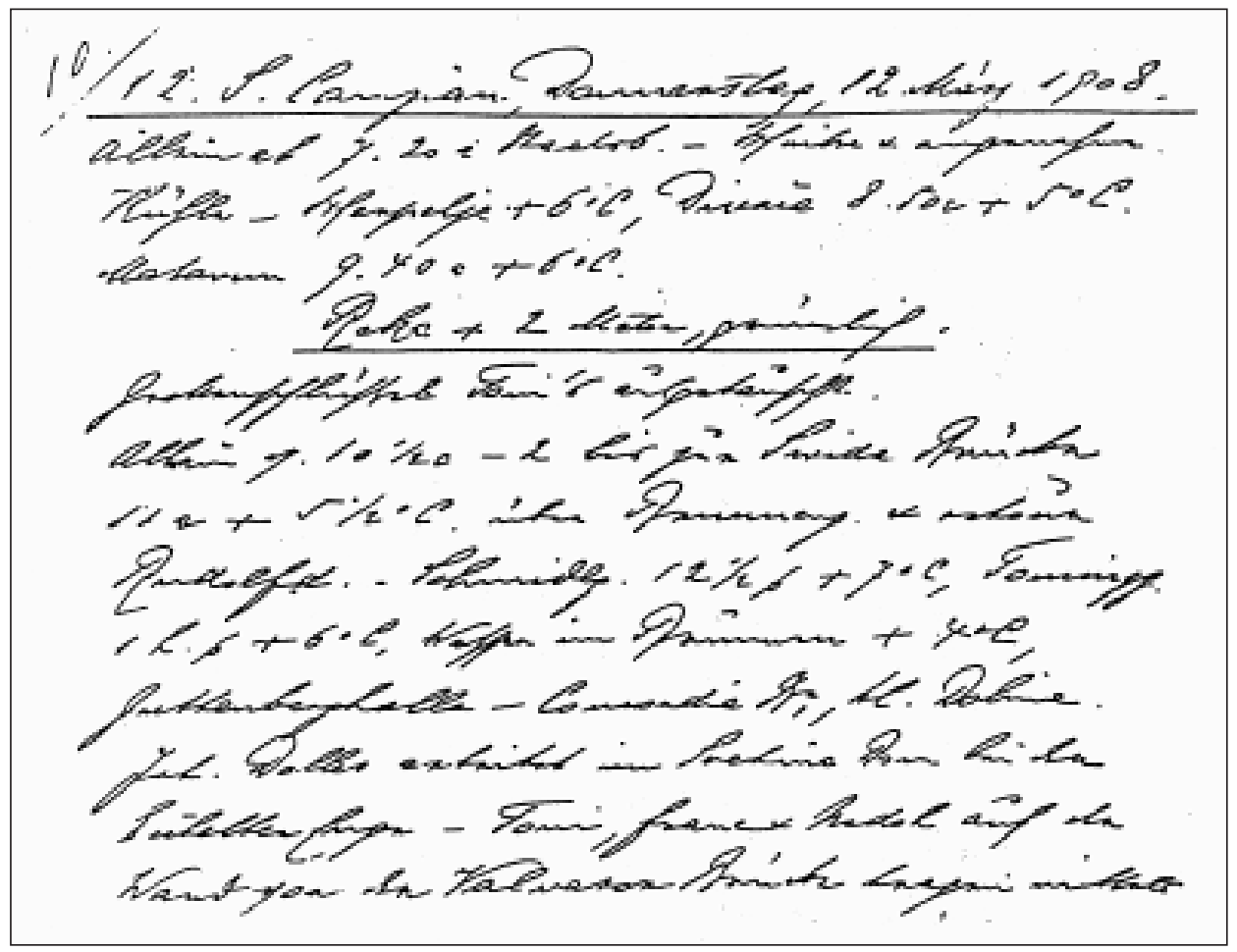

Fig. 1: An example of Marinitsch's entry into the "Grottenbuch" (12 th May 1908) (Kranjc 1996). 


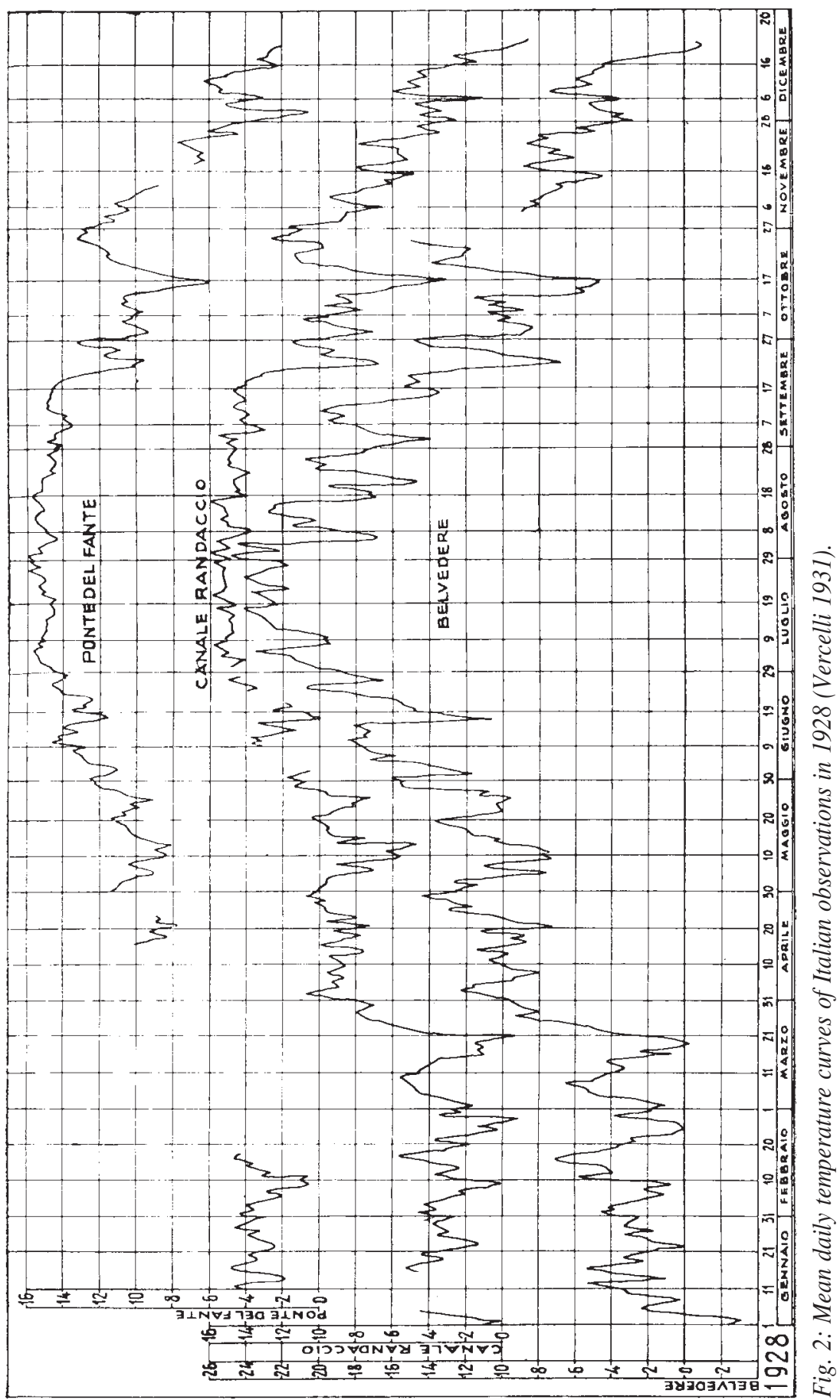




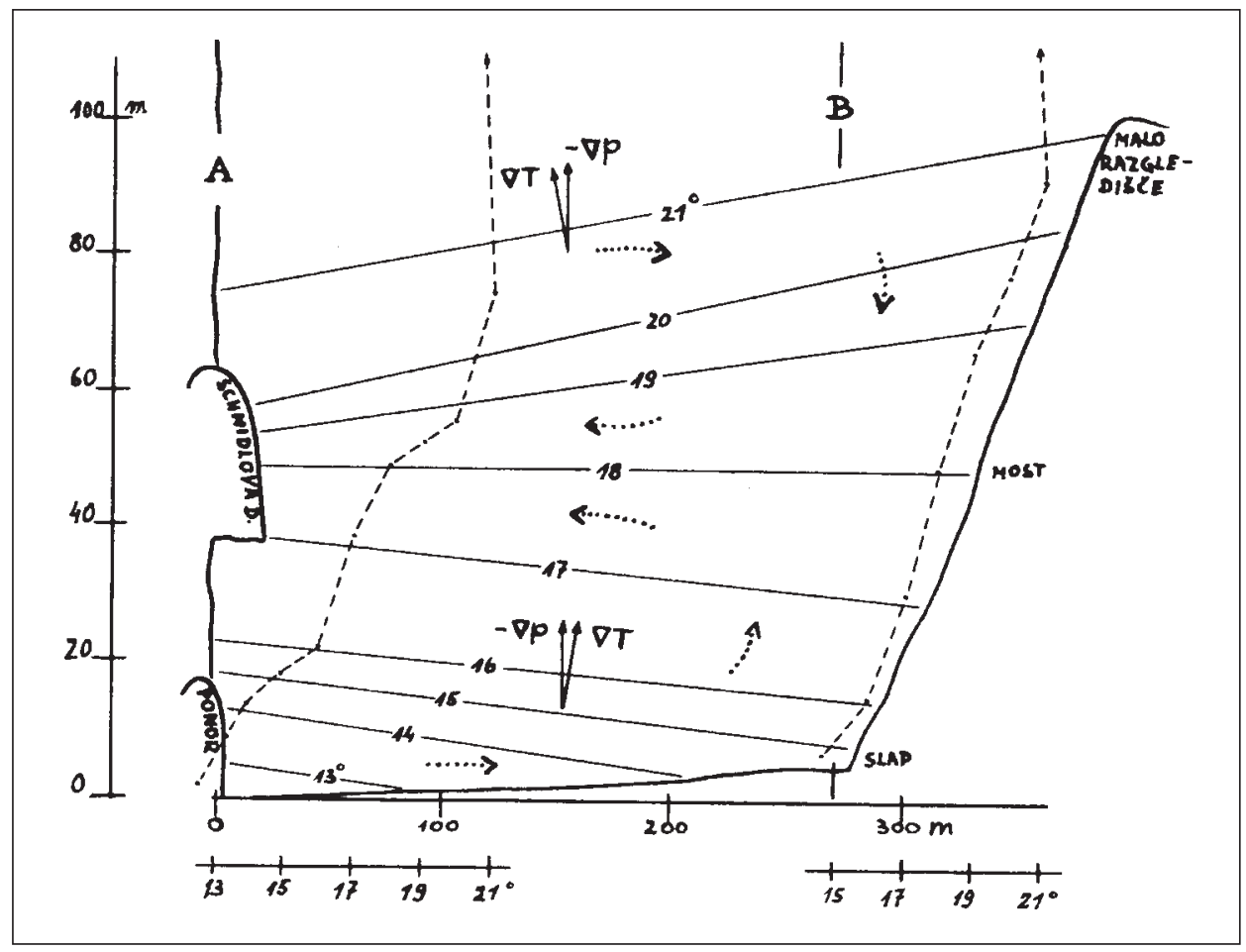

Fig. 3: Vertical cross-section of temperature field and circulation (Petkovšek 1968).

Through the years 1960-1962 the members of the Ljubljana University under the lead of Z. Petkovšek have carried out the meteorological observations in the cave and specially in the collapse doline Velika dolina. The main goal of the observations were temperature relations in Velika dolina (Fig. 3) (Petkovšek 1963). The temperature readings in the cave were of secondary importance only. "The measurements of air temperature in the cave were made $300 \mathrm{~m}$ from the entrance so being representative", as stated the author (Petkovšek 1968, 181). The average value of the outside air temperature was $12.6^{\circ} \mathrm{C}$ and that of the cave $9.6^{\circ} \mathrm{C}$. Taking into account the elevation difference between the surface and the cave passages, Petkovšek has found out that the cave is in an average about $4^{\circ} \mathrm{C}$ colder than the outside (Petkovšek 1968). Yearly amplitudes in the cave ranged approximately between $3{ }^{\circ} \mathrm{C}$ and $15^{\circ} \mathrm{C}$. Unfortunately it is not seen from the Petkovšek's paper where in the cave exactly they have been measuring the temperatures. Specially important has to be the position of the measurement point regarding the altitude above the floor of the passage that is of the Reka river. As it will be seen from our observations the difference between the temperatures near the ceiling and near the floor is essential. 


\section{7 - 1999 OBSERVATIONS AND THEIR RESULTS}

In 1992 Karst Research Institute started to monitor the temperatures with one thermograph. Later in co-operation with the research programme of University of Trieste, 5 temperature recorders were placed into different parts of the cave. The results of the two years (May 1997 - May 1999) were analysed and are presented in this paper.

Temperature recorders were set on different locations. The frequency of temperature reading was on an hourly basis. The temperature data were stored in recorders and each three months transmitted to the computer hard disk. For the mentioned two years we have 65,967 data at our disposal.

Location of temperature recorders (Fig. 4):

- At "Ponvice", $316 \mathrm{~m}$ a.s.l., about $50 \mathrm{~m}$ above the Reka river level, $70 \mathrm{~m}$ from the entrance at the bottom of Velika dolina. So-called "Dvorana Ponvic" (Ponvice Chamber) is largely open towards the main passage where the Reka river flows. It is dynamic part of the cave, with frequent current of air, shown by inclined stalactites too.

- Under Hankejev most (Hanke's bridge), $270 \mathrm{~m}$ a.s.1., $19 \mathrm{~m}$ above the Reka river level, $300 \mathrm{~m}$ from the entrance. This place floods often and the temperature recorder has been there half a year only. This is the main passage of the Reka river.

- At "Mačja brv" (Cat's footbridge), $316 \mathrm{~m}$ a.s.l., about $67 \mathrm{~m}$ above the Reka river level in the main passage of the Reka river, $430 \mathrm{~m}$ from the cave entrance. It can be said that this point is under the ceiling ( $7 \mathrm{~m}$ of vertical distance).

- Tiha jama, lateral passage, without underground river. The measuring point was at the bottom, $314 \mathrm{~m}$ a.s.1., $750 \mathrm{~m}$ from the Velika dolina and $250 \mathrm{~m}$ from the artificial entrance through the collapsed doline Globočak. The recorder did not show any difference in temperature $\left(11.4^{\circ} \mathrm{C}\right.$ constantly) and we have removed it. Other observations show the amplitudes there between $11^{\circ} \mathrm{C}-12.5^{\circ} \mathrm{C}$, in some parts even $13.5^{\circ} \mathrm{C}$.

- Upper station of the lift, $391 \mathrm{~m}$ a.s.l., on the upper boundary of the collapse doline Velika dolina. These data used to be compared with data got in the cave. The site does not represent outer (surface) temperatures very well, but we have put the instrument there from other points of view, firstly because of safety.

Important factor regarding the temperatures in the main river passage (Šumeča jama) is the river itself, its temperature and amount of water. We have included the data of the Reka river water temperatures for the year 1998 (the data have been provided by The Trieste University team). The temperatures were read $60 \mathrm{~m}$ in the cave, downstream from Velika dolina. Hydrometeorological Institute, Agency for the environment, provided us the data on discharge of the Reka river, about five kilometres upstream of the caves. These data served us just for the skeleton orientation and no serious analysis of interdependence between air and water temperatures, kinetics respectively, was made.

The results (Opara 2001), the previous one can be said, show that variation of the temperature in the observed parts of the cave, Tiha jama excluded, is substantial. It can be seen from the mean month temperatures (Fig. 5) as well as from the detailed observations.

Although the annual mean values are rather similar $\left(10.6^{\circ} \mathrm{C}\right.$ at Ponvice and $10.1^{\circ} \mathrm{C}$ at Mačja

brv), there is a great amplitude between the monthly mean values (under Hankejev most $1.6^{\circ} \mathrm{C}$ in 


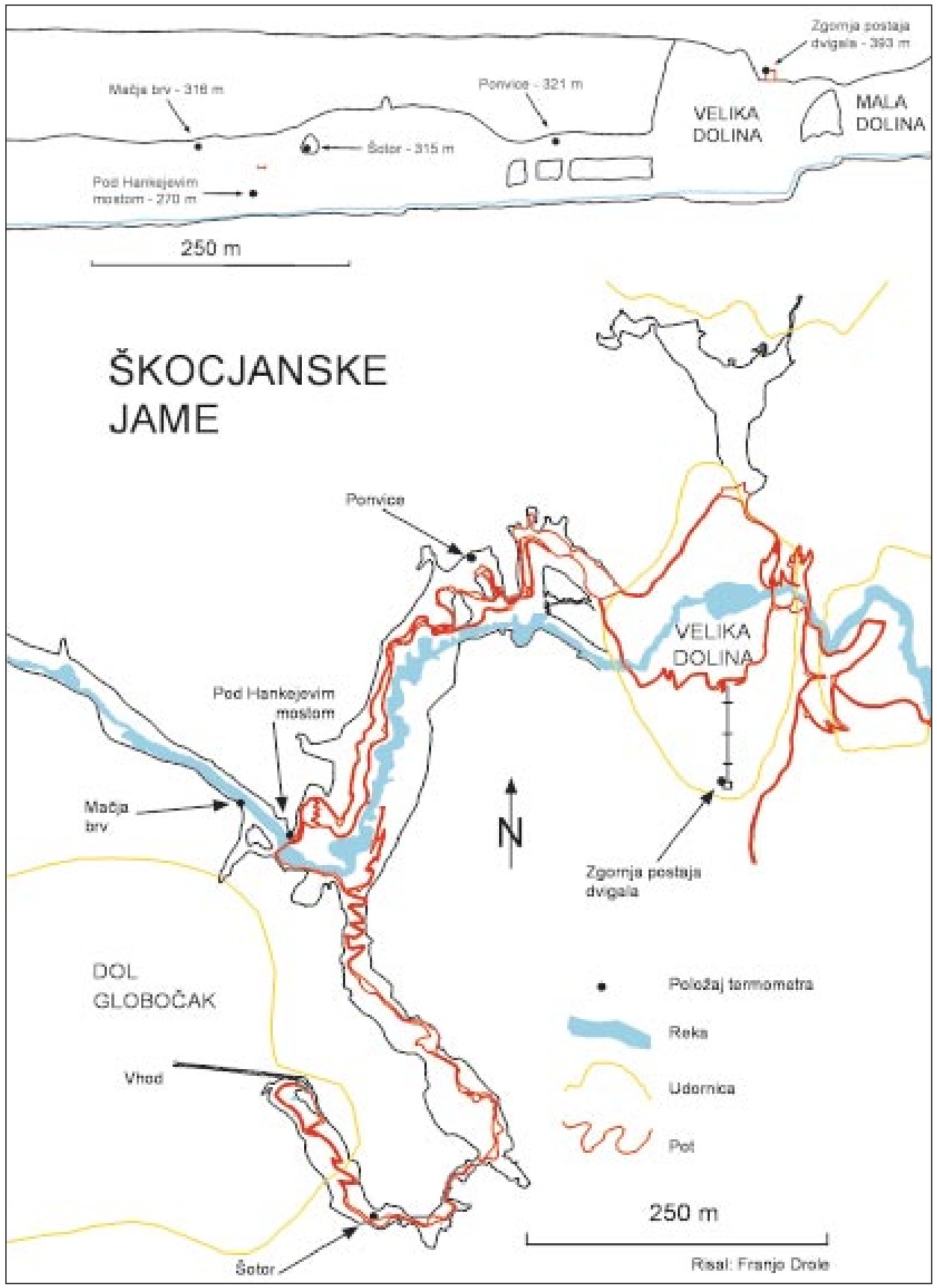

Fig. 4: Location of observation points during the years 1997-1999 in Škocjanske jame (drawn by F. Drole). 


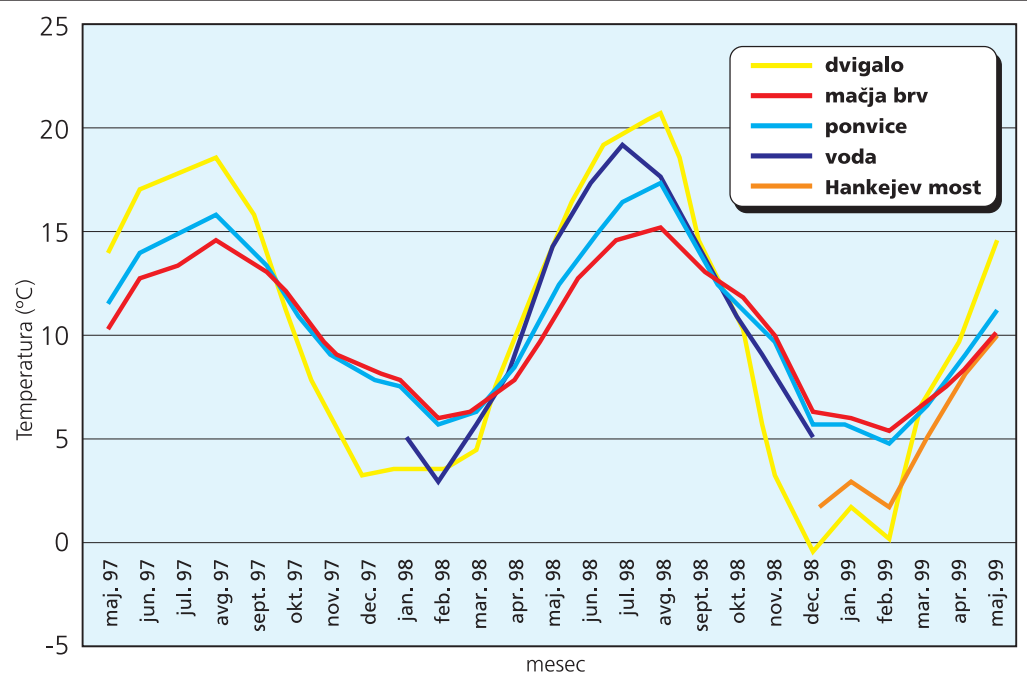

Fig. 5: Mean daily air and water temperature curves (May 1997 - May 1999) (dvigalo - elevator, voda - water) (Opara 2001).

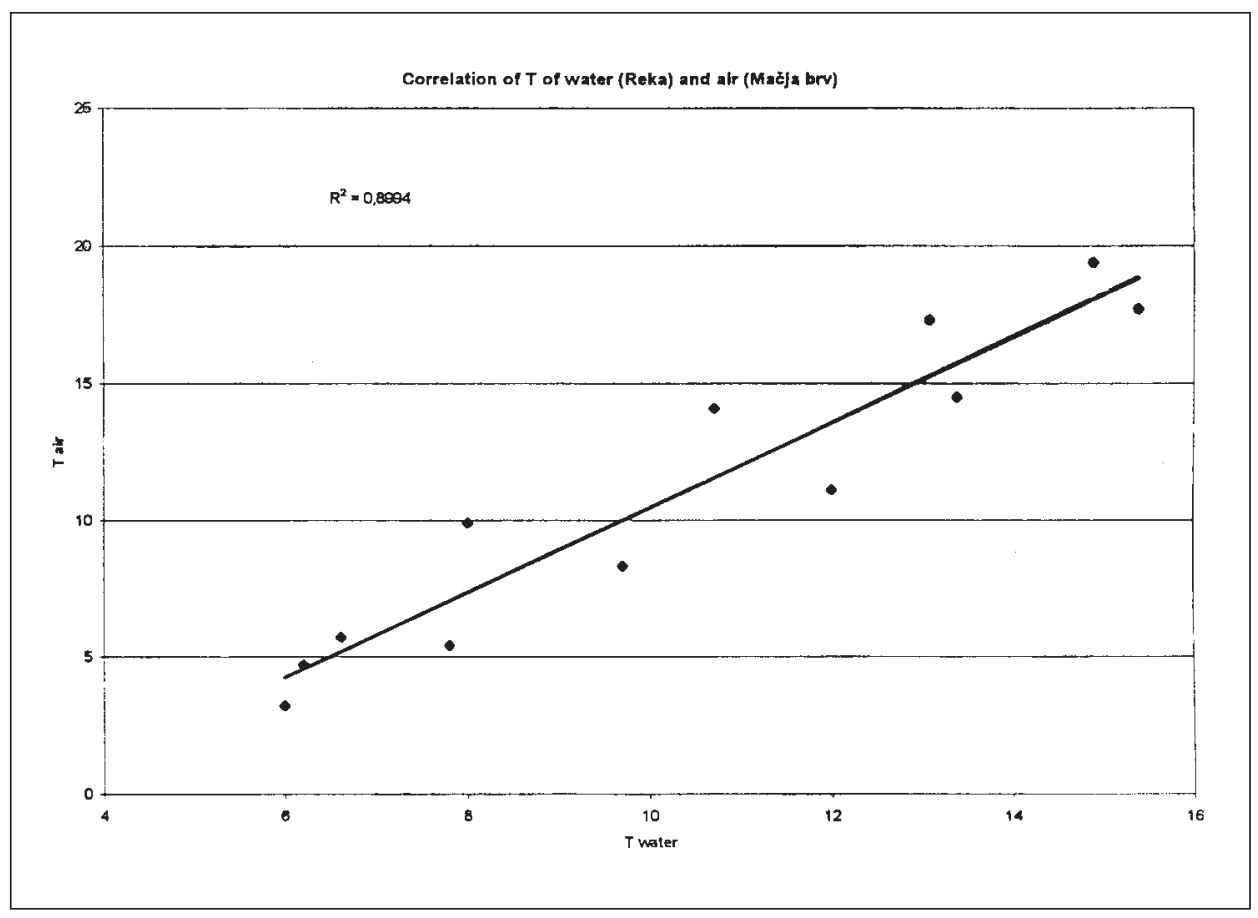

Fig. 6: Correlation of water (the Reka river) and air (Mačja brv) temperatures. 


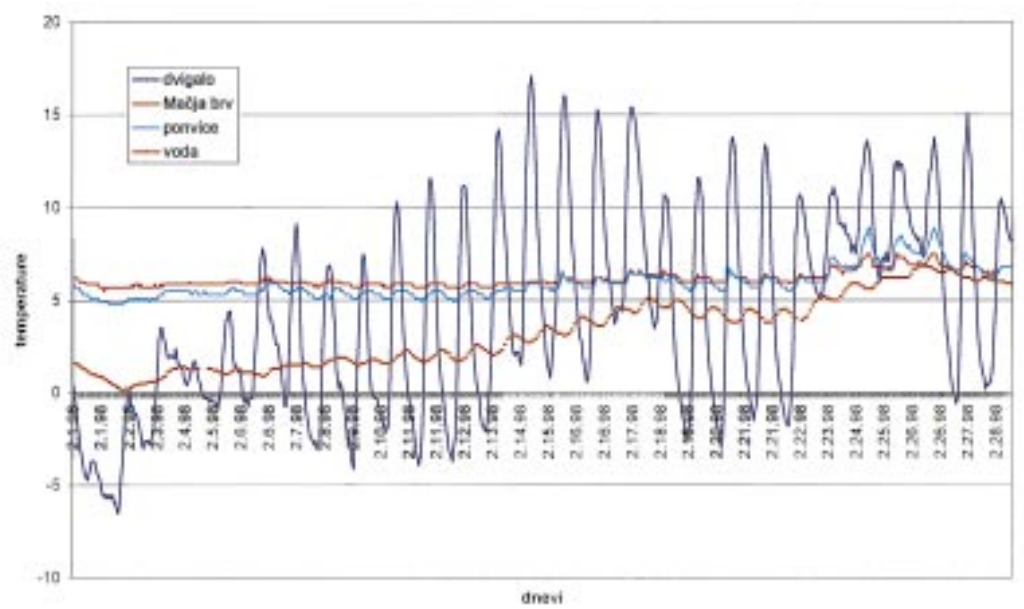

Fig. 7: Hourly air and water temperature curves (February 1998) (Opara 2001).

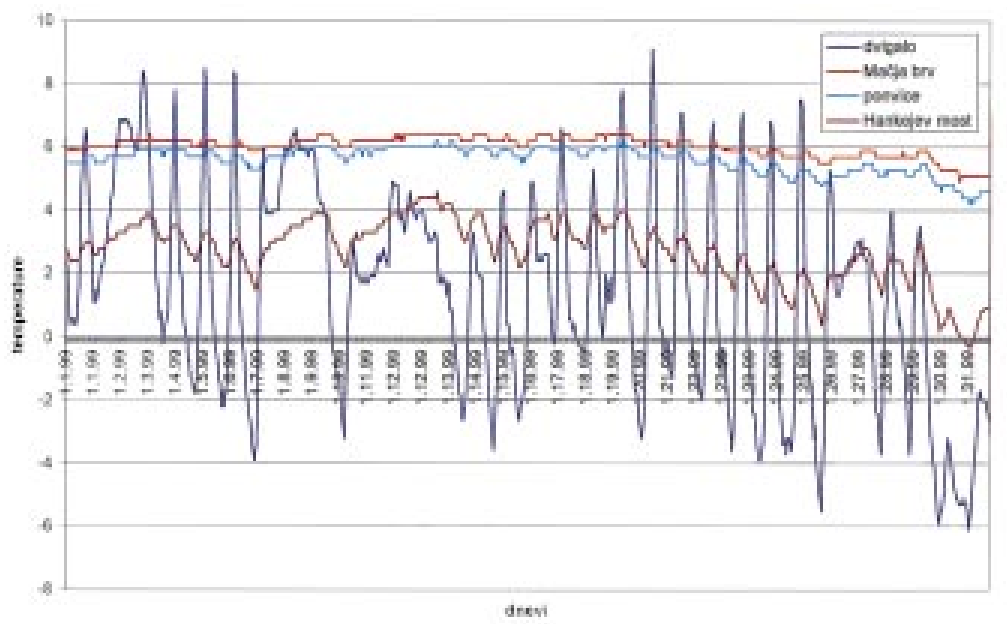

Fig. 8: Hourly air temperature curves (January 1999) (Opara 2001).

December and at Ponvice $17.3^{\circ} \mathrm{C}$ in August), while the absolute temperatures range between $-1.5^{\circ} \mathrm{C}$ under Hankejev most) and $21,9^{\circ} \mathrm{C}$ (Ponvice). The most important factors are distance from the entrance, which is evident, and the vertical position, that is the height above the bottom of the passage or above the underground river. The comparison between temperatures of the Reka river and the air temperatures near Mačja brv shows important correlation $\left(\mathrm{R}^{2}=0.8994\right)$ (Fig. 6). Of course it is not a proof that the water temperatures are essential for the changes of temperatures at 


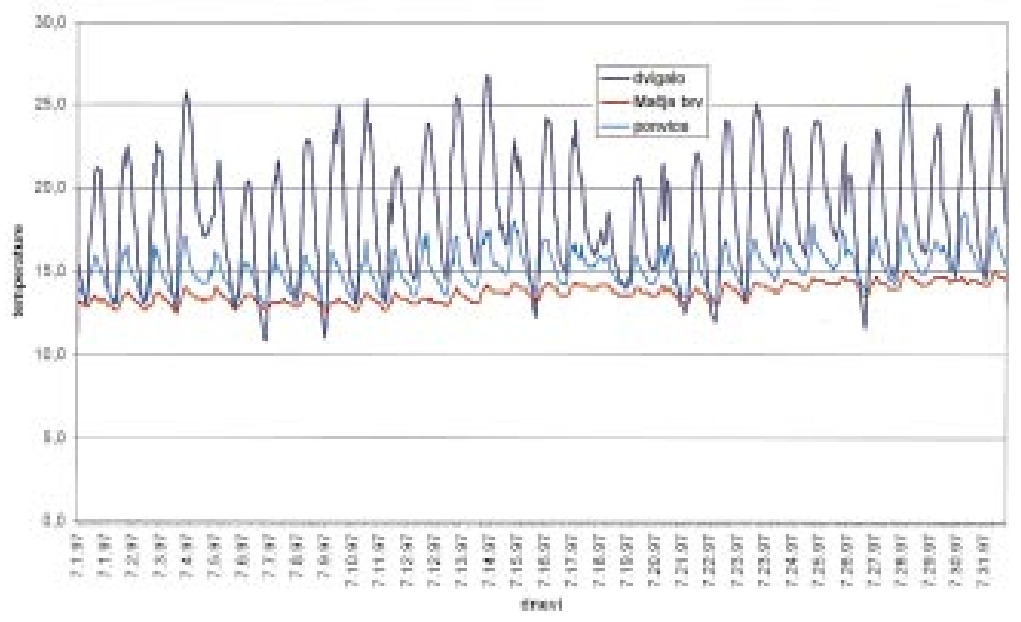

Fig. 9: Hourly air temperature curves (July 1997) (Opara 2001).

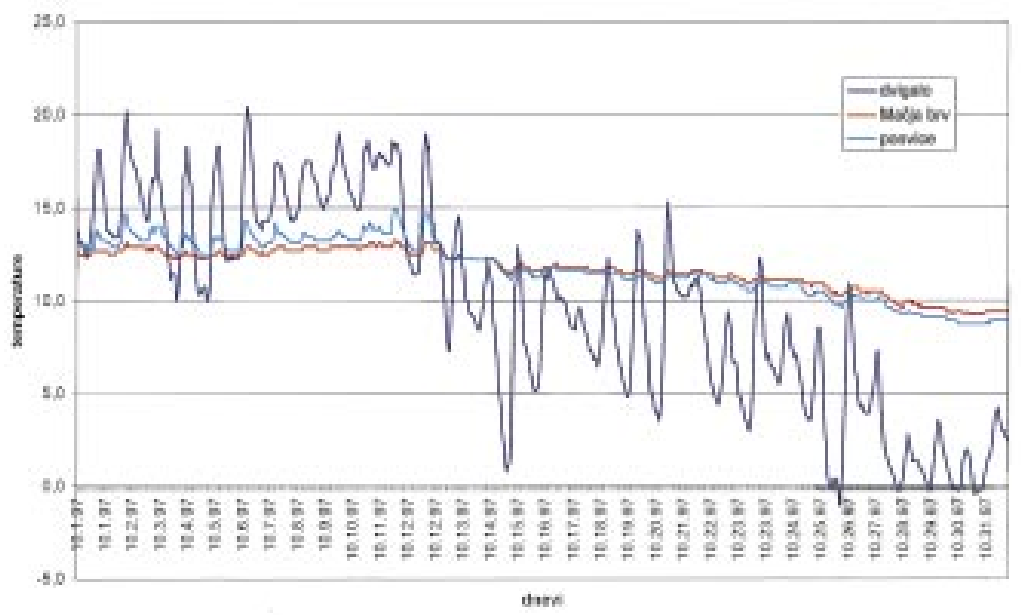

Fig. 10: Hourly air temperature curves (October 1997) (Opara 2001).

Mačja brv, for example. Trend is identical, but the amplitudes of water temperature are quite bigger than those of the air. In February 1998 the temperatures of water has been from $0^{\circ} \mathrm{C}$ to $7^{\circ} \mathrm{C}$, while of the air at Mačja brv they have been between $6^{\circ} \mathrm{C}$ and $8^{\circ} \mathrm{C}$ (Fig. 7).

It is clearly visible that in such large caves as Škocjanske jame are (at Hankejev most the passage is $72 \mathrm{~m}$ high, while in Martel's chamber it is up to $146 \mathrm{~m}$ even) the vertical position in the passage is very important for air temperature, its changes and amplitudes. In winter when outer temperatures are much lower, the daily amplitudes in the cave are relatively small, although outer 


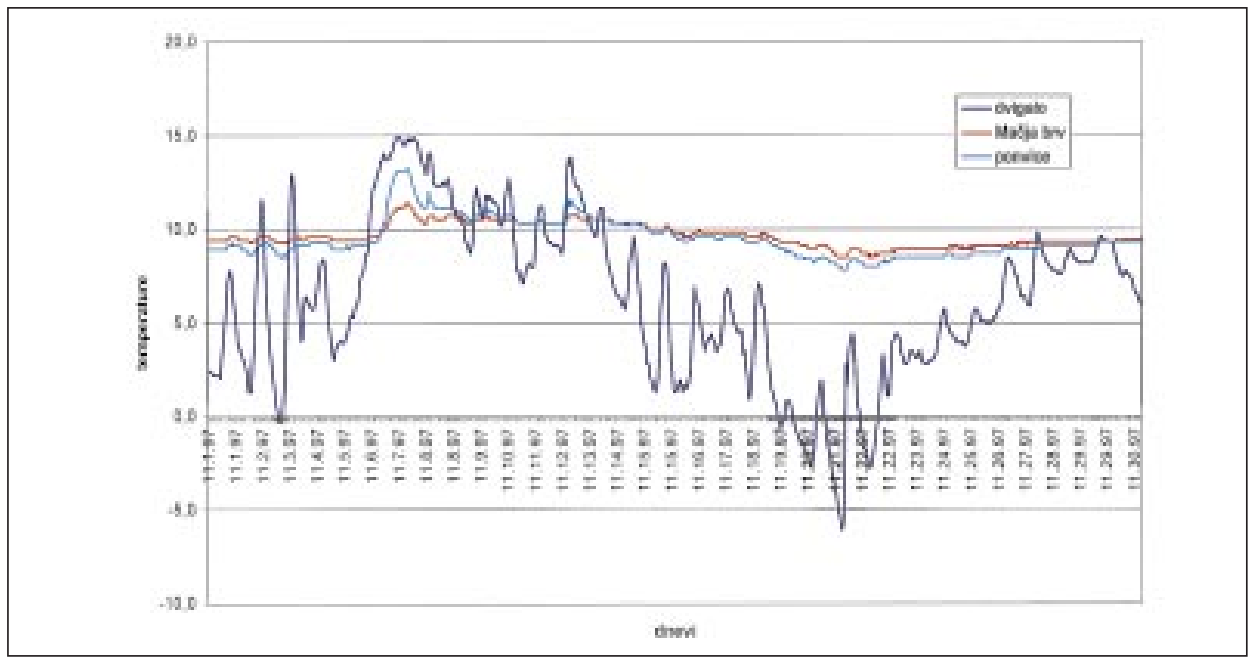

Fig. 11: Hourly air temperature curves (November 1997) (Opara 2001).

amplitudes can be important $\left(12^{\circ} \mathrm{C}\right)$ (Fig. 8, January 1999). When ouside temperatures are higher, it is just the opposite. Daily amplitudes are well expressed (Fig. 9, July 1997). Very illustrative is the situation in October 1997 (Fig. 10). First twelve days of the month the temperatures have been higher than the temperatures in the cave $\left(10^{\circ} \mathrm{C}-20^{\circ} \mathrm{C}\right)$ and then they dropped quickly under them (from 15 to under $0^{\circ} \mathrm{C}$ during the night). The graph for the first 12 days shows distinctive daily amplitudes and afterwards there is just a slowly falling line, daily amplitudes nearly imperceptible. Similar situation is when generally low outside temperatures suddenly rise, as in November 1997 (Fig. 11). Outside daily temperatures between $0^{\circ} \mathrm{C}$ and $12^{\circ} \mathrm{C}$ has risen for three days to $10^{\circ} \mathrm{C}$ $-15^{\circ} \mathrm{C}$ and then have fallen again, even down to $-6^{\circ} \mathrm{C}$. The rise of outside temperatures is reflected in cave by sudden rise for $2^{\circ} \mathrm{C}$ (Mačja brv) to $5^{\circ} \mathrm{C}$ (Ponvice). The repeated fall of outside temperatures reflects in slow (for 8 days) regular fall of the cave temperatures, from $11^{\circ} \mathrm{C}$ to $8^{\circ} \mathrm{C}$.

\section{CONCLUSIONS}

These preliminary results of the short-term observations already show that the part of Škocjanske jame, where the river Reka is flows, is an extremely dynamic cave and the visitors cannot have much impact on it's meteorology. From the cave air characteristics it would be good to know the vertical disposition of air temperatures in the vertical section of big passages along the Reka river in different situations, specially in different sesons (summer/winter). Due to the morphology of the caves and such great and fast temperature changes it is normal and were also observed relatively strong and fast air currents (wind) blowing in different directions in different seasons. Thus it would be necessary to include air current measurements into the monitoring programme.

On the contrary to cave passages along the Reka river, the hydrologicaly non-active passages included into the touristic circuit (Tiha jama) have by nature much more stable air properties and 
therefore it can be altered by the influence of tourist visit. This influence can be direct by the mass of the visitors or indirect by the tourist infrastructure, mostly because of illumination (heat and light). To detect the changes of the air characteristics due to tourists the instruments used during this previous monitoring were not adequate, as they were not sensible enough.

\section{REFERENCES}

Iviani, A., 1934: Guida delle grotte del Timavo a S. Canziano presso Divaccia e della Grotta Gigante presso Villa Opicina (Trieste).- CAI, 42 p.

Kranjc, A., 1996: Škocjanske jame, problems of the world heritage monument monitoring and safeguarding.- Show Caves and Environmental Monitoring Bossea 1995, 21-29, Cuneo

Opara, B., 2001: Temperature v Škocjanskih jamah - prispevek k speleoklimi.- Diplomsko delo (Diploma thesis), Filozofska fakulteta, Odd. za geografijo, 94 p., Ljubljana

Petkovšek, Z., 1963: Klimatske razmere v Veliki dolini pri Škocjanskih jamah.- Biološki vestnik, 11, 49-66, Ljubljana

Petkovšek, Z., 1968: Climatic conditions in the swallow-holes at cave entrances.- Proceed. $4^{\text {th }}$ Intern. Congress of Speleology 1965, Vol. 3, 181-188, Ljubljana

Vercelli, F., 1931: Il regime termico nelle Grotte di San Canziano.- Le Grotte d'Italia, 5, n.2, 49-62, Postumia

\section{OPAZOVANJE TEMPERATURE V ŠKOCJANSKIH JAMAH}

\section{Povzetek}

Leta 1884, ko je Jamarski odsek Primorske sekcije Nemško-Avstrijskega planinskega društva pričel raziskovati Škocjanske jame, je pričel eden izmed vodij raziskav, J. Marinitsch, meriti in zapisovati temperature v Škocjanskih jamah in njihovi okolici. Meritve za čas od leta 1886 do leta 1914 so bile zabeležene v njihovi "Höhlenbuch". Vse leto 1928 so potekale podrobne mikroklimatske meritve (s pomočjo petih termografov in petih minimalnih-maksimalnih termometrov) sočasno v podzemlju in na površju. V letih 1960 do 1962 so člani ljubljanske univerze pod Petkovškovim vodstvom opravljali meteorološka opazovanja v jami in posebej podrobno v udornici Veliki dolini. Leta 1992 so v okviru Inštituta za raziskovanje krasa ZRC SAZU pričeli z rednimi beleženji (monitoringom) temperature z enim termografom. Kasneje, v sodelovanju z raziskovalnim programom tržaške univerze, so v različne dele postavili 5 avtomatskih termometrov. Analizirani so rezultati dveletnih opazovanj (maj 1997 - maj 1999) ter predstavljeni v tem prispevku. Čeprav so si letni povprečki precej podobni $\left(10,6^{\circ} \mathrm{C}\right.$ in $\left.10,1^{\circ} \mathrm{C}\right)$, kažejo mesečni povprečki velika nihanja (od $1,6^{\circ} \mathrm{C}$ do $17,3{ }^{\circ} \mathrm{C}$ ), medtem ko so bile absolutne temperature $\mathrm{v}$ razponu od $-1,5^{\circ} \mathrm{C}$ do $21,9^{\circ} \mathrm{C}$. Najpomembnejša dejavnika za razporeditev temperature sta razdalja od vhoda in vertikalna pozicija. Primerjava temperature vode Reke in temperature zraka pri Mačji brvi kaže visoko stopnjo korelacije $\left(\mathrm{R}^{2}=0,8994\right)$. Predhodna opazovanja v tem kratkem času kažejo, da je ta del Škocjanskih jam, kjer teče Reka, izrazito dinamična jama in da obiskovalci ne morejo preveč vplivati na tamkajšnja meteorološka oziroma mikroklimatska dogajanja. 